\begin{tabular}{|l|c|c|c|}
\hline ACTA CLASSICA & LII. & 2016. & \\
UNIV. SCIENT. DEBRECEN. & & & pp. 149-161. \\
\hline
\end{tabular}

\title{
EARLY CHRISTIAN ARCHAEOLOGY IN HUNGARY BETWEEN 2010 AND 2016
}

\author{
BY LEVENTE NAGY
}

\begin{abstract}
In 2010 the Department of Archaeology at the University of Pécs witnessed the establishment of Christian Archaeology, a new M.A. subject that did not exist in Hungary before. Shortly after the launch of Christian Archaeology in Hungary, in 2012 the department started a new research project in collaboration with the Department of Christian Archaeology, University of Vienna, under the title Frühes Christentum in Ungarn. This contribution is a presentation of the most important events and research-results in Christian Archaeology in Hungary between 2010 and 2016. Recent publications of the Roman provincial archaeologists, migration period archaeologists and patristic philosophers and theologians are also taken into account.

Keywords: Early Christian archaeology, research projects, scientific collaborations, conferences, exhibition catalogues ${ }^{1}$.
\end{abstract}

In 2010 the Department of Archaeology at the University of Pécs witnessed the establishment of Christian archaeology, a new M.A. subject that did not exist in Hungary before. Shortly after the launch of Christian archaeology in Hungary, in 2012 the department started a new research project in collaboration with the Department of Christian Archaeology, University of Vienna, under the title Frühes Christentum in Ungarn. Project leaders Prof. Zsolt Visy (and since 2014 Levente Nagy) and Prof. Renate Johanna Pillinger, as well as other project members received funding from the Stiftung Aktion Österreich-Ungarn. ${ }^{1}$ The aim of the bilateral international project has been to write a new monograph on Early Christian monuments and artefacts found in the territory of Hungary, dated between the fourth and eighth centuries, with the contribution of various experts and M.A. and Ph.D. students from both Vienna and Pécs. The first project reports in 2012 and 2013 (published in German and English)

\footnotetext{
${ }^{1}$ This funding enabled both Austrian and Hungarian project members to travel throughout Hungary in order to observe Christian artefacts in Hungarian Museum magazines and exhibitions, and to visit libraries in Vienna in order to consult recently published Early Christian archaeological literature not known and read in Hungary before.
}

doi 10.22315/ACD/2016/11 
made a brief outline of the current state of research complemented with a research history beginning with the nineteenth century, paying homage to the former generations of researchers conducting investigations into Early Christian monuments and artefacts in Hungary. ${ }^{2}$

In the first two years of the project we made an EXCEL database of the examined Christian and presumably Christian finds and monuments, including data about their exact archaeological contexts (if there were any). In 2015 this database was converted into a Microsoft Word catalogue with appendices, which forms the basis of a future monograph. The analysis of the items in the catalogue started in 2012-2013, and will be continued in 2016 due to the courtesy and permissions of Hungarian museums. The project aims not only to collect recently published and unpublished material which have not been analysed and evaluated by earlier publications of the field. It also deals with new discussions and interpretations of the earlier published material employing modern evaluation methods and methodological approaches currently discussed in the research of Late Antiquity. The first students of Christian Archaeology in Hungary, Réka Neményi, Dalma Lukács and Nikolett Besenyi have already written their B.A./M.A. theses. They carried out in-depth analyses of fourth-century cross-bow brooches with Christian symbols ${ }^{3}$, Late Antique disc brooches with figural representations, ${ }^{4}$ and Menas ampullae of the Middle Danube Region ${ }^{5}$ with iconographical research offering new interpretations and new evidence about cross-cultural networks in the examined regions.

In the light of our project goals and aspirations, in this paper I will present a brief synthesis of Hungarian research concerning Early Christianity of Hungary between 2010 and 2016. The aim of my paper is not merely a presentation of the publications written by the research fellows and students of the Archaeology Departments in Pécs and Vienna employing special research methods and points of view of Christian archaeology (christliche Archäologie,

\footnotetext{
${ }^{2}$ Nagy 2013a, 325-330; Nagy 2015a; a more detailed synthesis of research history will be made by Tamás Szabadváry in his M.A. thesis of 2016 (Szabadváry 2016a). I especially thank the author for the possibility of reading the manuscript of his M.A. thesis still in progress. The first results of the project Frühes Christentum in Ungarn were presented in a poster exhibition in Pécs, in connection with the international conference titled Pagans and Christians in the Late Roman Empire: New Evidence, New Approaches, organised by the Department of Medieval Studies of the Central European University, Budapest and the Department of Archaeology of the Pécs University (Marianne Sághy - Levente Nagy): Nagy 2013a, 327, 334, Plate III. The conference papers will be published soon.

${ }^{3}$ Neményi 2012; Neményi 2014.

${ }^{4}$ Lukács 2016.

${ }^{5}$ Besenyi 2014.
} 
archaeologia Christiana) used in several departments and research centres in Europe. ${ }^{6}$ It is also meant to draw attention to the immense diversity of publications written by Hungarian archaeologists of the Roman provinces and the Migration Period, patristic philosophers, and theologians dealing with the same era.

In 2010, along with the establishment of the discipline of Christian archaeology in Hungary and the organisation of a poster exhibition and a conference in Istanbul on the Late Roman - Early Christian heritage of Sopianae and the Province of Valeria, ${ }^{7}$ the Hungarian Patristic Society (the most relevant organised research community dealing with various aspects of Early Christianity in Hungary since 2001) witnessed on its annual conference in Kecskemét a strong increase of interest in methodological problems of Early Christian art and iconography: how to interpret (re-interpret) images with the help of biblical and patristic texts. ${ }^{8}$ This interest was extended to a collaboration with the BARDA Research Group for Early Christian Iconography and Epigraphy at King's College, London. The conference organised together with the Center of Patristic Studies of the University of Pécs on 24-25 May 2012 in Pécs focused on iconographical questions related to the murals in the burial chambers of Sopianae. ${ }^{9}$ The papers of the conference titled Early Christian Art: An International Conference with special regard to the early Christian Cemetery in Sopianae (PécsHungary) were published in the series Studia Patristica in Oxford, in 2014. ${ }^{10}$

The systematic re-evaluation of the iconographical programs of Early Christian casket mounts with mythological and Biblical scenes from Hungary began in 2012. Some of the results are still available in the manuscripts of conference papers, being prepared for publication. ${ }^{11}$ A new synthesis about the Early Christian murals from Hungary are being prepared in connection with the project Frühes Christentum in Ungarn by Claudia-Maria Behling and Krisztina Hudák. The results of earlier publications by Krisztina Hudák and Levente Nagy about the paintings of Sopianae published between 2003 and 2016 were

\footnotetext{
${ }^{6}$ A recent introductory synthesis of the specific methods, interests and viewpoints of Christian archaeology: Sörries 2013.

${ }^{7}$ Fazekas - Gábor - Nagy - Visy 2010.

${ }^{8}$ Bugár 2014b; Heidl 2014 (in English: Heidl 2013); Nagy 2013b (German manuscript for the series Specimina Nova, English summary: Nagy 2014, 203-205).

${ }^{9}$ Shortly reported by Nagy 2013a, 326-327, 331 .

${ }^{10}$ Brent 2014; Bugár 2014a; Csigi 2014; Heidl 2014; Hudák 2014; Nagy 2014a, with the promise of a new synthesis of the Early Christian iconography of the Pannonian provinces; Visy 2014.

${ }^{11}$ Nagy 2012a; Nagy 2014b (English: Nagy 2016a); Nagy 2013b (German manuscript for the series Specimina Nova; English: Nagy 2014a, 203-205.); Nagy 2015b (German manuscript for the series Antaeus); Nagy 2015c (Hungarian manuscript for the series Studia Patrum).
} 
summarized briefly at the AIPMA international conference in Lausanne, on 16 September 2016. ${ }^{12}$

The excavations of the Late Roman - Early Christian funerary buildings in the northern cemetery of Sopianae between 2000 and 2006, in 2010-2011 and 2015 raised several new questions of interpretation concerning the structure, reconstruction possibilities and religious historical evaluation of funerary buildings. Did all of the two-storey burial chambers in Pécs (sharing obviously the same architectural design) belong to Christians, or only those with symbols and Biblical images expressing clearly Christian identity? Were they commissioned by the local (otherwise unknown) church authorities, or were they ordered by private commissioners? What should the correct definition and terminology of these buildings be: hypogaea, crypts, burial chambers, cellae memoriae, burial chapels, or mausolea? These issues have been discussed in detail in various publications between 2010 and $2016 .{ }^{13}$ The most recent synthesis is the new monograph of Olivér Gábor from 2016, based on the updated version of his Ph.D. dissertation from 2008. ${ }^{14}$

Early Christian Church history and hagiography are special Hilfswissenschaften of Christian archaeology. A new Church history in the Pannonian provinces between 374 and 456 is offered by Krisztina Hudák in her Ph.D. dissertation from 2013 (defended in 2014). ${ }^{15}$ The still missing updated summary of the Church history of Pannonia from the time of the Tetrarchy to 374 is in progress (Krisztina Hudák - Levente Nagy). The relevant contributions by Rajko Bratož and the collections of written sources of Late Roman Pannonia, published continuously by Péter Kovács, are particularly useful. ${ }^{16}$ The Research Centre of Church History established at the University of Pécs in 2012 launched its new monograph series titled Thesaurus Historiae Ecclesiasticae in

\footnotetext{
${ }^{12}$ Hudák - Nagy 2016 (English manuscript for the AIPMA conference). An earlier manuscript of Levente Nagy from 2011 about the afterlife concepts concerning the Pécs murals designed for the series Autonomous Towns in Noricum and Pannonia could be published finally in the series Hungarian Polis Studies in 2016, in the Festschrift for György Németh, professor of ancient history in Budapest: Nagy 2016b.

${ }^{13}$ Gábor 2010; Gábor 2013; Gábor 2014; Katona Győr 2013, 177-181; Pozsárkó - Tóth I. Zs. 2011; Magyar 2012, 131-134; Tóth I. Zs. 2010; Tóth I. Zs. 2012a; Tóth I. Zs. 2012b; Tóth I. Zs. 2015.

${ }^{14}$ Gábor 2016.

${ }^{15}$ Hudák 2013.

${ }^{16}$ Bratož 2011a; Bratož 2011b; Kovács 2011; Kovács 2014; Kovács 2016. A short collection of recent publications in the field of Church history of Pannonia is summarized by Nagy 2016c, $169-170$, which is a book review of the posthumous edition of the famous Pannonian religious history by István Tóth: Tóth I. 2015. Recent historical summary of Arian Gepids: Kiss 2015, 124-129.
} 
Universitate Quinqueecclesiensi with a hagiographical and archaeological interpretation experiment of four Passion stories from Pannonia. ${ }^{17}$ Another relevant research topic of the centre for the year 2016 is the complex theoretical and case-study based investigation of Christianisation as a historical process in the Carpathian Basin from the Early Christian period to the Middle Ages. The next conference in collaboration with the Hungarian Academy of Sciences and the new Research Centre of Christianisation founded this year by the Department of Archaeology at the University of Pécs will be held with the title Christianisation: Identity, Mobility, Continuity on 14 October 2016 in Pécs.

The Bishopric of Pécs has recently become strongly interested in Early Christian research. In 2015 the diocese established a new Christian Heritage Research Centre dealing with Early Christian art and archaeology, too. One of the first events of the new centre was a joint international conference with the collaboration of the Department of Archaeology in Pécs, the Hungarian Academy of Sciences and the University of Vienna, Institute of Classical Archaeology (organised by Günther Schörner, Réka Neményi and Levente Nagy) with the title Archaeology of Identiti(es) - Archäologie der Identität(en) on 12-13 November 2015. One of the methodological questions at the conference was an experiment: how to employ the special research methods and theoretical frameworks of post-processual archaeology and archaeology of identity in the research of Early Christianity in Pannonia. ${ }^{18}$

In the years in question (2010-2016) archaeologists of the Roman provinces prepared new publications about earlier excavated finds on Roman sites with Christian interpretations ${ }^{19}$ (such as a bronze finger-ring with a Chi-Rho emblem from the Late Roman cemetery of Visegrád-Diós, ${ }^{20}$ two lead seals and a bronze finger-ring from the Iseum of Savaria, ${ }^{21}$ a magical (?) amulet from the Southern cemetery of Intercisa ${ }^{22}$ ), or long-forgotten unpublished artefacts from museum magazines (such as, a bronze mirror fragment with crosses from Intercisa in the magazine of the Hungarian National Museum ${ }^{23}$ ).

Endre Tóth, a renowned expert on Late Antique archaeology of Pannonia from the last third of the 20th century till today, continued his earlier work on the passio S. Quirini, ${ }^{24}$ on the Late Roman - Early Christian inscriptions from

\footnotetext{
${ }^{17}$ Nagy $2012 b$.

${ }^{18}$ Nagy 2015d.

${ }^{19}$ For example some evidence from County Baranya: Gábor - Katona-Győr 2012.

${ }^{20}$ Grave No. 134: Gróh 2015, 72-73, fig. 3/7.

${ }^{21}$ Kat. Szombathely 2013, 291, Kat. Nr. 26.2-4

${ }^{22}$ Near graves No. 1624 and 1625: Szabó 2014, 209-221, figs. 1, 2, 4.

${ }^{23}$ Szabadváry 2016b, 293-298, figs. 1a-d; see further Kocsis 2013.

${ }^{24}$ Tóth E. 2011a
} 
the Eastern Cemetery of Savaria, ${ }^{25}$ or on questions of continuity of the so-called Romanized population in the Migration Period. ${ }^{26} \mathrm{He}$ summarized his earlier iconographical analysis of the casket mount fragments from the inner fortress of Ságvár, ${ }^{27}$ and his typological considerations of the cross-bow brooches of types Keller 5/6 - Pröttel 5/6 - Swift 5i-ii/6i-ii. He evaluated the brooches with Christian symbols from Ságvár, Tömlöc-hill, grave No. 7 and from a Late Roman grave in Tihany-Sajkod. ${ }^{28}$

Regarding the younger generations of Roman provincial archaeology, I had the possibility to follow the extremely useful M.A. thesis project of Tamás Szabadváry. He re-collected and re-evaluated the Early Christian artefacts from the Hungarian National Museum, reconstructing their original contexts (old excavations, purchase from individuals) from inventory books and museum archives. $^{29}$

Archaeologists of the Migration Period continued to deal with fifth- and sixth-century Christian finds and monuments from Roman sites - for example, the Late Roman fortress of Aquincum, ${ }^{30}$ the town of Scarbantia ${ }^{31}$ or the inner fortress of Keszthely-Fenékpuszta, together with their surroundings ${ }^{32}$ - raising several challenging questions of continuity, mobility, migrations, and interpretations of ethnicity. Concerning the recent (or reiterated) chronological, contextual and religious historical interpretations of Christian artefacts from the fifth to the eighth century from the Carpathian Basin, ${ }^{33}$ the contributors tried to make the same attempts to reconstruct or refuse a kind of religious syncretism $(! ?)^{34}$, personal beliefs, ethnic/cultural identity, mobility or special cultural contacts with the Eastern Mediterranean, based on the funerary context of the de-

${ }^{25}$ Tóth E. 2011b, 188-200.

${ }^{26}$ Tóth E. 2013b

${ }^{27}$ Tóth E. 2014

${ }^{28}$ Tóth E. 2015, especially 337-340.

${ }^{29}$ Szabadváry $2016 \mathrm{a}$

${ }^{30}$ Zsidi 2011; Vida 2013; Tóth 2013a, 48.

${ }^{31}$ Tomka 2015, 600, 612.

${ }^{32}$ Heinrich-Tamáska 2011a; Heinrich-Tamáska 2011 b (in German: Heinrich-Tamáska 2010); Heinrich-Tamáska 2012; Heinrich-Tamáska 2015, 45-58; Heinrich-Tamáska 2016; HeinrichTamáska - Müller - Straub 2012, 49-58; Müller 2010; Müller 2014, 157-173; Vida 2011, 413-418.

${ }^{33}$ See, for example, Bollók 2014; Bollók 2016; Curta 2011, 305-313; Daim-Bühler 2012, 208-217; Heinrich-Tamáska - Straub 2015, 636-638; Perémi 2012, especially 470-471; Prohászka 2012, 49-51; Vida 2016, 87-88.

${ }^{34}$ For the methodological questions of the use of this term/concept and other terms/concepts discussed in recent Early Christian studies, see Nagy 2016d (this manuscript in German for the conference titled Grenzübergänge, held in Ruma on 6 November 2015, will be published in the same conference volume). 
ceased with one or two Christian artefacts (necklaces, pectoral crosses, apotropaic (?) amulets, disc brooches, and agraffes).

These methodological tendencies are also present in the most recent summary of Hungarian research on Early Christianity in the Carpathian Basin: in the new catalogue of the two exhibitions in Szombathely and Pannonhalma on the occasion of the supposed year of birth of St. Martin, bishop of Tours. ${ }^{35}$ The catalogue of the St. Martin exhibition, comprising some unpublished material (for example, lead seals with Christian symbols and Biblical scenes from the Hungarian National Museum ${ }^{36}$ ) and coloured photographs of good quality, is a really successful synthesis of the investigated time-span of the development of Early Christian archaeological research in Hungary between 2010-2016. The next step on this way must be the monograph Frühes Christentum in Ungarn to be published by the Austrian Academy of Sciences.

\section{Bibliography}

Besenyi 2014 = Besenyi, N.: A Közép- és Al-Duna-vidéki Menas ampullák ikonográfiai elemzése (The iconographical analysis of Menas ampullae in the Middle and Lower Danube Region). B.A. thesis, University of Pécs, Department of Archaeology.

Bratož 2011a = Bratož, R.: Die Auswanderung der Bewölkerung aus den pannonischen Provinzen während des 5. und 6. Jahrhunderts. In: Konrad, M. - Witschel, C. (eds.): Römische Legionslager in den Rhein- und Donauprovinzen - Nuclei frühmittelalterlichen Lebens? BAW Phil.-Hist. Klasse, Abhandlungen, Neue Folge 138. München, 589-614.

$-2011 \mathrm{~b}=$ Bratož, R.: Die kirchliche Organisation in Westillyricum (vom späten 4. Jh. bis um 600). In: Heinrich-Tamáska, O. (ed.): Keszthely-Fenékpusza im Kontext spätantiker Kontinuitätsforschung zwischen Noricum und Moesia, CPP 2. Budapest-Leipzig-KeszthelyRahden/Westfalen, 211-248.

Brent $2014=$ Brent, A.: Methodological Perspectives in the Interpretation of Early Christian Artefacts. StPatr 73, 1-38.

Bollók 2014 = Bollók, Á.: Bellerophon and crucifixion? A brief note on circular box brooches form Pannonia. In: Heinrich-Tamáska, O. - Straub, P. (eds.): Mensch, Siedlung und Landschaft im Wechsel der Jahrtausende am Balaton - People, Settlement and Landscape on Lake Balaton over the Millennia, CPP 4. Budapest-Leipzig-Keszthely-Rahden/Westfalen, 259-279.

— 2016 = Bollók, Á.: A Fifth-century Scriptural Amulet from Hács-Béndekpuszta in its Mediterranean Context. In: Bollók, Á.- Csiky, G. - Vida, T. (eds.): Between Byzantium and

${ }^{35}$ Kat. St. Martin 2016, with the archaeological contributions of Ádám Bollók, Orsolya Heinrich-Tamáska, Attila P. Kiss, Ágota Perémi, and Tivadar Vida. The archaeological evidence on Late Roman Pannonian Christianity is briefly summarized in the contributions of Endre Tóth, Zsolt Visy and Krisztina Hudák with Levente Nagy (the name of co-author Krisztina Hudák is mistakenly missing from the Hungarian edition of the catalogue).

${ }^{36}$ Kat. St. Martin 2016, 210-211, Kat. Nr. III.33a-u. 
the Steppe. Archaeological and Historical Studies in Honour of Csanád Bálint on the Occasion of his $70^{\text {th }}$ Birthday. Budapest, 31-62 (in press, non vidi).

Bugár 2014a = Bugár, I. M.: Theology of Images? Some Observations on the Murals in the Peter and Paul Burial Chamber of Pécs. StPatr 63, 281-295.

— 2014b = Bugár, I. M.: Dominus legem dat. Quam et cui? In: D. Tóth, J. - Heidl, Gy. (eds.): Studia Patrum V. Irodalom, teológia, müvészet (Literature, Theology, Art). Budapest, 244-262

Curta $2011=$ Curta, F.: New Remarks on Christianity beyond the $6^{\text {th }}$ and early $7^{\text {th }}$ century frontier of the Roman Empire. In: Heinrich-Tamáska, O. (ed.): Keszthely-Fenékpuszta im Kontext spätantiker Kontinuitätsforschung zwischen Noricum und Moesia, CPP 2. Budapest-LeipzigKeszthely-Rahden/Westfalen, 303-321.

Csigi 2014 = Csigi, P.: Deliberate Ambiguities in Early Christian Wall Paintings in Sopianae. StPatr 63, 237-248.

Daim-Bühler 2012 = Daim, F. - Bühler, B.: Awaren oder Byzanz? Interpretationsprobleme am Beispiel der goldenen Mantelschliesse von Dunapataj. In: Vida, T. (ed.): Thesaurus avarorum. Régészeti tanulmányok Garam Éva tiszteletére - Archaeological Studies in Honour of Éva Garam. Budapest, 207-224.

Fazekas - Gábor - Nagy - Visy $2010=$ Fazekas, F. - Gábor, O. - Nagy, L. - Visy, Zs.: A késő római kor és az ókereszténység Sopianae és Valeria területén. Geç Roma dönemindeki Sopianae ve Valeria-Erken Hristiyanlık. Sopianae and Valeria in the Late Roman Age-Early Christianity, Specimina Nova Suppl. 10. Pécs.

Gábor 2010 = Gábor, O.: Die altchristliche(n) Kirche(n) von Sopianae. In: Erdős, Z. - Kindl, M. (eds.): Pécs az egyháztörténet tükrében. Tanulmányok (Pécs in the mirror of Church History. Studies). Pécs, 47-60.

— 2011 = Gábor, O.: Sopianae pogány és ókeresztény temetkezései (Pagan and Early Christian Burials in Sopianae). In: Fekete, M. (ed.): „Eleitől fogva“. A 75 éves Makkay Jánost köszöntő kötet ("From the beginnings." Papers in Honour of János Makkay on the Occasion of his $75^{\text {th }}$ Birthday), Specimina Nova Suppl. 11 = Vivarium Fontium 6. Pécs, 55-74.

— 2013 = Gábor, O.: Sopianae ókeresztény temetőjének épületei (Buildings of the Late Roman Cemetery of Sopianae). In: Vonyó, J. - Visy, Zs. (eds.): Pécs története I. Az öskortól a püspökség alapításáig (History of Pécs from Prehistoric Times until the Foundation of the Bishopric). Pécs, 195-222 (English: 351).

— 2014 = Gábor, O.: Early Christian Buildings in the Northern Cemetery of Sopianae. StPatr 73, $39-57$.

— 2016 = Gábor, O.: Sopianae késö antik temetöi épületei (Late Antique Cemetery Buildings in Sopianae), Kaposvár-Pécs.

Gábor - Katona Győr 2012 = Gábor, O. - Katona Győr, Zs.: Ókeresztény tárgyak Baranyából (Early Christian Artefacts from County Baranya). Pécsi Szemle 15/4, 2-10.

Gróh 2015 = Gróh, D.: A Visegrád-diósi késö császárkori temetö keresztény emlékeiröl (Christian Remains from the Roman Imperial Period Cemetery at Visegrád-Diós), Hadak útján 26. Budapest-Esztergom, 71-79.

Heidl 2013 = Heidl, Gy.: Early Christian Imagery of the 'virga virtutis' and Ambrose's Theology of Sacraments. StPatr 59, 69-76.

$-2014=$ Heidl, Gy.: Remarks on the Iconography in the "Peter-Paul" (No. 1.) Burial Chamber of Sopianae. StPatr 73, 219-236.

Heinrich-Tamáska 2010 = Heinrich-Tamáska, O.: Sakral- oder Profanbauten? Zur Funktion und Datierung der „Kirchen” von Keszthely-Fenékpuszta (Komitat Zala, Ungarn). In: Krohn, N. (ed.): Kirchenarchäologie heute. Fragestellungen - Methoden - Ergebnisse, Veröffentlichung des Alemannischen Instituts, Freiburg im Breisgau 76. Darmstadt, 91-112. 
— 2011a = Heinrich-Tamáska, O.: Pannonische Innenbefestigungen und römische Kontinuität: Forschungsstand und Perspektiven. In: Konrad, M. - Witschel, C. (eds.): Römische Legionslager in den Rhein- und Donauprovinzen - Nuclei frühmittelalterlichen Lebens? BAW Phil.-Hist. Klasse, Abhandlungen, Neue Folge 138. München, 571-588.

- 2011b = Heinrich-Tamáska, O.: Megjegyzések a fenékpusztai II. sz. kora keresztény bazilika keltezéséhez (Bemerkungen zur Datierung der zweiten frühchristlichen Basilika von Fenékpuszta). MFMÉ Stud. Arch. 12, 225-234.

- 2011c = Heinrich-Tamáska, O.: Die spätrömische Innenbefestigung von Keszthely-Fenékpuszta. Innere Chronologie und funktioneller Wandel. In: Heinrich-Tamáska, O. (ed.): Keszthely-Fenékpuszta im Kontext spätantiker Kontinuitätsforschung zwischen Noricum und Moesia, CPP 2. Budapest-Leipzig-Keszthely-Rahden/Westfalen, 653-702.

- 2012 = Heinrich-Tamáska, O.: Fortleben, Abbruch und Neuanfang: Spuren des Christentums in Pannonien im 4.-9. Jahrhundert. In: Heinrich-Tamáska, O. - Krohn, N.- Ristow, S. (eds.): Christianisierung Europas. Entstehung, Entwicklung und Konsolidierung im archäologischen Befund. Christianisation of Europe: Archaeological evidence for its creation, development and consolidation, Internationale Tagung im Dezember 2010 in Bergisch Gladbach. Regensburg, 213-237.

— 2015 = Heinrich-Tamáska, O.: Civitates et castra im Lichte der Konti-nuitäsforschung: zwei Beispiele aus Pannonien (5.-7. Jh. n. Chr.). In: Heinrich-Tamáska, O.- Herold, H. - Straub, P. - Vida, T. (eds.): „Castellum, civitas, urbs”. Zentren und Eliten in frühmittelalterlichen Ost-mitteleuropa - Centres and Elites in Early Medieval East-Central Europe, CPP 6. Budapest-Leipzig-Keszthely-Rahden/Westfalen, 45-69.

— 2016 = Heinrich-Tamáska, O.: Une époque de bouleversement? Remarques sur l'étude de l'antiquité tardive et de la paléochrétienté en Pannonie. In: Bollók, Á. - Csiky, G. - Vida, T. (eds.): Between Byzantium and the Steppe. Archaeological and Historical Studies in Honour of Csanád Bálint on the Occasion of His $70^{\text {th }}$ Birthday. Budapest, 31-62 (in press, non vidi).

Heinrich-Tamáska - Müller - Straub 2012 = Heinrich-Tamáska, O. - Müller, R. - Straub, P.: A fenékpusztai római erőd évszázadai (Centuries of the Roman fort in Fenékpuszta). Zalaegerszeg.

Hudák 2013 = Hudák, K.: A kereszténység története a Kárpát-medencében 374-456 között (The History of Christianity in the Carpathian Basin between 374 and 456). Ph.D. dissertation, Eötvös Loránd University, Budapest.

- 2014 = Hudák, K.: Technical Observations on the Paintings in the St. Peter and Paul (No. 1.) Burial Chamber in Sopianae, StPatr 73, 249-279.

Hudák - Nagy 2016 = Hudák, K. - Nagy, L.: Research on Roman Wallpainting in Hungary between 2004 and today: interpreting and reinterpreting the evidence. Manuscript submitted to the XIIIe Colloque de l' Association Internationale pour la Peinture Murale Antique (AIPMA), Université de Lausanne, 12-16 Septembre 2016.

Katona Györ 2013 = Katona Győr, Zs.: Temetkezési szokások a római kori Sopianaeben (Burial Rites in Sopianae in the Roman Period). In: Vonyó, J. - Visy, Zs. (eds.): Pécs története I. Az őskortól a püspökség alapításáig (History of Pécs from Prehistoric Times until the Foundation of the Bishopric). Pécs, 153-194 (English: 349-351).

Kat Carnuntum 2014 = Humer, F. - Kremer, G. - Pollhammer, E. - Pülz, A. (eds.): A.D. 313. Von Carnuntum zum Christentum. Ausstellung im Archäologischen Museum Carnuntinum, Bad Deutsch-Altenburg März 2013 - Oktober 2016. Bad Vöslau.

Kat St. Martin 2016 = Tóth, E. - Vida, T. - Takács, I. (eds.): Szent Márton és Pannónia. Kereszténység a római világ határán (St. Martin and Pannonia. Christianity at the Frontier of the Roman World), Pannonhalma, Apátsági Múzeum, 2016. június 3. - szeptember 18 - Szom- 
bathely, Iseum Savariense, 2016. június 3. - november 30. Pannonhalma-Szombathely. [English volume in press.]

Kat Szombathely 2013 = Sosztarits, O. - Balázs, P. - Csapláros, A. (eds.): Iseum Savariense - A savariai Isis szentély I. Isis savariai otthona - kiállitási katalógus (The sanctuary of Isis in Savaria I. The Home of Isis in Savaria - Exhibition catalogue), Sistrum Series A Nr.1. Szombathely.

Kiss 2015 = Kiss, P. A.: „, ...ut strenui viri”. A gepidák Kárpát-medencei története (The History of the Gepids in the Carpathian Basin). Szeged. English summary: 281-289.

Kocsis $2013=$ Kocsis, L.: A New Piece with a Chi-Rho from the Roman Collection of the Hungarian National Museum, ActaArchHung 64, 113-129.

Kovács 2011 = Kovács, P. (ed.): Fontes Pannoniae Antiquae in aetate Tetrarcharum I. (A.D. 285-305). Az ókori Pannonia forrásai az I. tetrarchia korában (Kr. u. 285-305.). Budapest

— 2014 = Kovács, P.: Die antiken Quellen zu Pannonien in der Spätantike. Teil I: 284-337 n. Chr. Wien.

— 2016 = Kovács, P.: A history of Pannonia in the Late Roman period I. (284-363 AD.), Antiquitas I, 67. Bonn.

Lukács 2016 = Lukács, D.: Újabb adatok a késő antik figurális diszitésü korongfibulák ábrázolásainak értelmezési problémáihoz (Recent Data to the Interpretation Problems of Late Antique Disc Brooches with Figural Representations). M.A. thesis, University of Pécs, Department of Archaeology.

Magyar 2012 = Magyar, Zs.: Késő császárkori sírépületek Pannoniában (Late Roman Mausolea in Pannonia). ArchÉrt 137, 125-144.

Müller 2010 = Müller, R.: Die Gräberfelder vor der Südmauer der Befestigung von KeszthelyFenékpuszta mit Beiträgen von Erzsébet Fóthi, Ágnes Kustár, Adrien Pásztor, Katalin T. Rendes, CPP 1, Budapest-Leipzig-Keszthely-Rahden/Westfalen.

Müller 2014 = Müller, R.: Die Gräberfelder von Keszthely-Fenékpuszta, Ödenkirche-Flur. CPP 5, Budapest-Leipzig-Keszthely-Rahden/Westfalen.

Nagy 2012a = Nagy, L.: Bemerkungen zum ikonografischen Programm des frühchristlichen Kästchenbeschlags von Császár (Ungarn), MiChA 18, 61-90.

— 2012b = Nagy, L.: Pannóniai városok, mártírok, ereklyék. Négy szenvedéstörténet helyszínei nyomában (Cities, Martyrs, Relics in Pannonia. Discovering the Topography of four Pannonian Passion Stories), Thesaurus Historiae Ecclesiasticae in Universitate Quinqueecclesiensi 1. Pécs. English summary: 221-227.

- 2013a $=$ Nagy, L.: Early Christianity in Hungary. A New Research Project, Specimina Nova 21-22, 325-334.

— 2013b (in press) $=$ Nagy, L.: Interpretationsprobleme des frühchristlichen Kästchenbeschlags mit Lazarus-Darstellung von Ságvár, Grab 54. Manuscript submitted to the serie Specimina Nova in 2013.

— 2014a = Nagy, L.: Zoltán Kádár and the Early Christian Iconography of Roman Pannonia. Some Problems of Interpretation, StPatr 73, 195-218.

$-2014 b=$ Nagy, L.: Hercules és Iuppiter, Krisztus és Konstantin. A szentendrei ókeresztény ládikaveret ikonográfiai programja (Hercules und Iuppiter, Christus und Konstantin. Das ikonografische Programm des frühchristlichen Kästchenbeschlags von Szentendre). In: Tóth, O. (ed.): Studia Moralia. Acta officinae programmate „OTKA” sustentatae in aedibus Universitatis Scientiarum Debreceniensis redacta, Hereditas Graeco-Latinitatis I. Debrecen, 124-140.

— 2015a = Nagy, L.: Die Lage der Erforschung des frühen Christentums in Ungarn im Spiegel eines neuen Projekts. In: Pillinger, R. (ed.): Neue Forschungen zum frühen Christentum in 
den Balkanländern, ÖAW, Phil.-Hist. Klasse, Denkschriften 484 - Archäologische Forschungen 26. Wien, 19-36.

- 2015b (in press) = Nagy, L.: Beiträge zum ikonografischen Programm der frühchristlichen Kästchenbeschläge aus Intercisa, Südfriedhof, Grab 109. Manuscript submitted to the series Antaeus in 2015.

$-2015 \mathrm{c}=$ Nagy, L.: Orpheus, az eszményi költő. Késő antik Orpheus-ábrázolások keresztény kontextusban (Orpheus, the Ideal Poet. Late Antique Representations of Orpheus in Christian Context). Paper held at the $15^{\text {th }}$ conference of the Hungarian Patristic Society in Pécs, June 2015, will be submitted to the volume Studia Patrum IX.

- 2015d = Nagy, L.: Aspects of $4^{\text {th }}$ Century Christian Identity in the Late Roman Province Valeria. Paper delivered at the International Conference Archäologie der Identitäten - Archaeology of Identities in Pécs, on 12 November 2015.

- 2016a = Nagy, L.: Myth and Salvation in Fourth Century. Representations of Hercules in Christian Contexts. In: Salzman, M. - Sághy, M. - Lizzi Testa, R. (eds.): Pagans and Christians in Late Antique Rome. Conflict, Competition and Coexistence in the Fourth Century. Cambridge, 377-398.

$-2016 \mathrm{~b}=$ Nagy, L.: Jenseitsvorstellungen und ihre Interpretationsprobleme im spätrömischen frühchristlichen Gräberfeld von Sopianae/Pécs. In: Szabó, Á. - Gradvohl, E. (eds.): From Polites to Magos. Studia György Németh sexagenario dedicata. HPS 22, 210-229.

- 2016c $=$ Nagy, L.: Gondolatok Tóth István pannoniai vallástörténetéröl (Some Ideas About the Religious History of Pannonia by István Tóth). Budapest, 2015. Korall 64, 158-174.

— 2016d (in press) = Nagy L.: Ein frühchristliches Denkmal aus Ungarn. Methodische Interpretationsprobleme - unscharfe Terminologie. Manuscript submitted to the conference volume „, Grenz Übergänge”. ,, Spätrömisch”, ,, frühchristlich ”, ,frühbyzantinisch” als Kategorien der historisch-archäologischen Forschung an der mittleren Donau (4.-8. Jh.) - "Late Roman", "early Christian", "early Byzantine" as categories in historical and archaeological research in the Middle Danube Region (A.D. $4^{\text {th }}-8^{\text {th }}$ century). 27. Internationales Symposium Grundprobleme der frühgeschichtlichen Entwicklung im mittleren Donauraum in Ruma, 4-7. November 2015.

Neményi 2012 = Neményi, R.: Adalékok a Krisztus-monogrammal díszített hagymafejes fibulák értelmezési problémáihoz (Addenda to the Interpretation Problems of the Cross-Bow Brooches with a Christogram). In: Szamonek, V. (ed.): X. Országos Interdiszciplináris Grastyán Konferencia Elöadásai (Contributions to the $10^{\text {th }}$ Hungarian Interdisciplinary Conference in Honour of Endre Grastyán). Pécs, 272-281.

— 2014 = Neményi, R.: Ókeresztény szimbólummal ellátott késő antik hagymafejes fibulák a római birodalomban (Late Antique Cross-bow Brooches with Early Christian Symbols in the Roman Empire). M.A. Thesis, University of Pécs, Department of Archaeology.

Perémi 2012 = Perémi, Á.: Keresztmellékletes sírok a Lesencetomaj-Piroskereszt temetőből (Gräber mit Kreuzbeigaben im Gräberfeld Lesencetomaj-Piroskereszt). In: Vida, T. (ed.): Thesaurus avarorum. Régészeti tanulmányok Garam Éva tiszteletére - Archaeological Studies in Honour of Éva Garam. Budapest, 437-476.

Pozsárkó - Tóth I. Zs. 2011 = Pozsárkó, Cs. - Tóth, I. Zs.: Pécs in den römischen Zeiten. Wegweiser zu den Schauplätzen des Welterbes in Pécs. Pécs

Prohászka 2012 = Prohászka, P.: Az Ozora-tótipusztai avar fejedelmi sírok. (Die awarischen Oberschichtsgräber von Ozora-Tótipuszta). Budapest. German summary: 97-101.

Sörries 2013 = Sörries, R.: Spätantike und frühchristliche Kunst. Eine Einführung in die christliche Archäologie. Köln-Weimar-Wien. 
Szabadváry 2016a = Szabadváry, T.: Ókeresztény vonatkozású római tárgyak a Magyar Nemzeti Múzeum gyüjteményében (Roman Artefacts with Early Christian Connections in the Collection of the Hungarian National Museum). M.A. thesis, manuscript, Budapest, Eötvös Loránd University.

- 2016b = Szabadváry, T.: An "old-new" late Roman mirror from the collection of the Hungarian National Museum. In: Szabó, Á. - Gradvohl, E. (eds.): From Polites to Magos. Studia György Németh sexagenario dedicata, HPS 22, 293-298.

Szabó 2014 = Szabó, A.: Bonus scarabeus. An Early Christian (?) magical gem from Pannonia. In: Németh, Gy.- Bajnok, D. (eds.): Miscellanea Historiae Antiquitatis. Proceedings of the First Croatian-Hungarian Ph.D. Conference on Ancient History. HPS 21, 221-237.

Tomka 2015 = Tomka, P.: Eine römische Stadt und ihre barbarische Peripherie: Scarbantia. In: Vida, T. (ed.): Romania Gothica II. The frontier world. Romans, Barbarians and the military culture. Budapest, 587-615.

Tóth E. 2011a = Tóth, E.: Utószó Szt. Quirinus vértanú szenvedéstörténetéhez (Afterword to the Passion story of St. Quirinus). In: Balogh, A.: Szt. Quirinus vértanú püspök (The Martyr Bishop St. Quirinus), (reprint). Szombathely.

— 2011b = Tóth, E.: Lapidarium Savariense. Savaria feliratos köemlékei (Stone Monuments from Savaria), Savaria 34/2. Szombathely.

— 2013a = Tóth, E.: A korai kereszténység a mai főváros területén (I.-V. század). (Early Christianity in the Territory of the Modern Capital $\left(1^{\text {st }}-5^{\text {th }}\right.$ century)) In: Beke, M. (ed.): A katolikus Budapest I. Általános történeti szempontok. Plébániák. (The Catholic Budapest. General Historical Points of View. Parishes.) Budapest, 38-48.

$-2013 b=$ Tóth, E.: Titkos keresztények az avar korban (Secret Christians in the Avarian Period). In: Tóth, O. - Forisek, P. (eds.): Ünnepi kötet Gesztelyi Tamás 70. születésnapjára (Papers in Honour of T. Gesztelyi on the Occasion of his $70^{\text {th }}$ Birthday). Debrecen, 203-220.

— 2014 = Tóth, E.: Der heilige Timotheus in Pannonien. Bronzene Kästchenbeschläge aus der spätrömischen Innenbefestigung von Ságvár. In: Heinrich-Tamáska, O. - Straub, P. (eds.): Mensch, Siedlung und Landschaft im Wechsel der Jahrtausende am Balaton. (People, Settlement and Landscape on Lake Balaton over the Millennia), CPP 4. Budapest-LeipzigKeszthely-Rahden/Westfalen, 125-136.

- 2015 = Tóth, E.: Typologie der nicht gegossenen Zwiebelknopffibel. In: Vida, T. (ed.): Romania Gothica II. The Frontier World. Romans, Barbarians and Military Culture. Budapest, 329-361.

Tóth I. 2015 = Tóth, I.: Pannoniai vallástörténet (Pannonian Religious History). Budapest.

Tóth I. Zs. 2010 = Tóth, I. Zs.: A Cella Septichora Pécs első középkori székesegyháza? (Is the Cella Septichora the First Medieval Cathedral of Pécs?). Pécsi Szemle 13/2, 3-14.

— 2012a = Tóth, I. Zs.: Hány sírkamrát rejt a föld Sopianae északi temetőjében? (How many Burial Chambers are Hidden in the Northern Cemetery of Sopianae?). Pécsi Szemle 15/1, 2-15.

— $2015=$ Tóth, I. Zs.: Jelentés a pécsi székesegyház nyugati oldala előtt, a Cella Trichora I.-től északra végzett megelőző (hitelesítő) régészeti feltárásról (2013.10.30-2013.12.11) és a Cella Trichora I. védőépületének bontása során végzett régészeti felügyeletről (2014. 01.08 2014. 03. 19.) (Rescue Excavation Reports from the Territory to the North of the Cella Trichora No. 1. in Front of the Western Gate of the Cathedral between 10.30. 2013 11.12.2013 and between 08.01.2014 - 19.03.2014). Archaeológia - Altum Castrum online, 130.

Tóth I. Zs. - Pozsárkó 2012b = Tóth, I. Zs. - Pozsárkó, Cs.: Újabb ókeresztény sírkápolna Sopianaeből (Another Early Christian Burial Chapel from Sopianae). Ókor 2012/1, 97-106. 
Vaday 2013a = Vaday, A.: Lovas szent és az arkangyal ábrázolásai az avar korból (The Representation of a Holy Rider and the Archangel from the Avar Period). Magyar Régészet Online Magazin (Hungarian Archaeology E-Journal) 2013 Spring. http://www.magyarregeszet.hu/wp-content/uploads/2013/04/Vaday_13T.pdf

— 2013b = Vaday, A.: Pécs története az avar kortól a magyar honfoglalásig (The History of Pécs from the Avar Period until the Foundation of the Hungarian State). In: Vonyó, J. - Visy, Zs. (eds.): Pécs története I. Az öskortól a püspökség alapitásáig (History of Pécs from Prehistoric Times until the Foundation of the Bishopric). Pécs, 233-265 (English: 352-357).

Vida 2011a = Vida, T.: Das Gräberfeld neben dem Horreum in der Innenbefestigung KeszthelyFenékpuszta. In: Heinrich-Tamáska, O. (ed.): Keszthely-Fenékpuszta im Kontext spätantiker Kontinuitätsforschung zwischen Noricum und Moesia, CPP 2, Budapest-Leipzig-KeszthelyRahden/Westfalen, 397-456.

$-2011 \mathrm{~b}=$ Vida, T.: Die Zeit zwischen dem 4. und 6. Jahrhundert im mittleren Donauraum aus archälogischer Sicht. In: Konrad, M. - Witschel, C. (eds.): Römische Legionslager in den Rhein- und Donauprovinzen - Nuclei spätantik-frühmittelalterlichen Lebens? BAW Phil.Hist. Klasse, Abhandlungen, Neue Folge 138. München, 615-648.

— 2013 = Vida, T.: A népvándorlás kori kereszténység a mai főváros területén (VI-IX. század) (Christianity in the Territory of the Modern Capital in the Migration Period (A.D. $6^{\text {th }}-9^{\text {th }}$ century)). In: Beke, M. (ed.): A katolikus Budapest I. Általános történeti szempontok. Plébániák. (The Catholic Budapest. General Historical Points of View. Parishes.) Budapest, 49-55.

- 2016 = Vida, T.: Late Antique Metal Vessels in the Carpathian Basin. Luxury and Power in the Early Middle Ages (Hereditas Archaeologica Hungariae). Budapest.

Visy 2013 = Visy, Zs.: Sopianae településtörténete (Settlement History of Sopianae). In: Vonyó, J .Visy, Zs. (eds.): Pécs története I. Az öskortól a püspökség alapításáig (History of Pécs from Prehistoric Times until the Foundation of the Bishopric). Pécs, 92-152 (English: 345-348). - $2014=$ Visy, Zs.: The Paradise in the Early Christian Cemetery of Sopianae. StPatr 73, 59-73.

Zsidi 2011 = Zsidi, P.: Vom spätantiken Aquincum zum mittelalterlichen Vetus Buda (Altofen). In: Konrad, M. - Witschel, C. (eds.): Römische Legionslager in den Rhein- und Donauprovinzen - Nuclei spätantik-frühmittelalterlichen Lebens? BAW Phil.-Hist. Klasse, Abhandlungen, Neue Folge 138. München, 551-560.

\author{
Abbreviations \\ ActaArchHung - Acta Archaeologica Academiae Scientiarum Hungariae \\ BAW - Bayerische Akademie der Wissenschaften \\ CPP - Castellum Pannonicum Pelsonense \\ HPS - Hungarian Polis Studies \\ MFMÉ Stud. Arch. - Móra Ferenc Múzeum Évkönyve, Studia Archaeologica \\ MiChA - Mitteilungen zur Christlichen Archäologie \\ StPatr - Studia Patristica
}

(ISSN $0418-453 X)$ 